\title{
Boon or Bane? Discursive Construction of the Shale Gas Controversy
}

\author{
Zeynep Cihan Koca-Helvacı
}

ZEYNEP.KOCA@DEU.EDU.TR

\author{
School of Foreign Languages, Dokuzçeşmeler Yerleşkesi, \\ Dokuz Eylul University 35160/ Buca Izmir/TURKIYE
}

Editor: David Traum

Submitted 11/2016; Accepted 06/2017; Published Online 11/2017

\begin{abstract}
This study explores strategies in pro and anti-shale organizations' discourse by combining the Discourse-Historical Approach (Wodak, 2001) with corpus linguistics. With the help of keyword lists, collocations, concordances, and key semantic domains, the representations of shale gas extraction, relevant actors and argumentation schemes in opposing discourses of the pro-shale Marcellus Shale Coalition and anti-shale Americans Against Fracking were analysed. The findings of the study show that the advocates presented shale gas as a bonus for the crisis-struck American society through discourse of altruism and solidarity. The opponents, on the other hand, represented shale gas as a threat to the American ecosystem and public health through an alarming and scientific discourse. The empirical findings of this study add to a growing body of literature on discursive strategies employed by opposing camps of environmental controversies.

Keywords: shale gas, environmental issues, the Discourse-Historical Approach, corpus linguistics, discursive strategies
\end{abstract}

\section{Introduction}

Depletion of conventional energy resources, growing demand for energy, and advanced drilling technologies have led many energy companies to steer towards unconventional sources of fossil fuel like shale gas. The extraction process involves horizontal drilling and hydraulic fracturing which means drilling and injecting chemical solvent at high pressure into the hole to crack the rock formations so that trapped methane gas in the miniscule pores of shale deposits can be released (Finewood \& Stroup, 2012). The extraction of shale gas is also known as (hydraulic) fracturing, fracking, or fracing.

Since the mid-2000s, the increasing demand for fracturing has sharply polarized society. The advocates claim that the extraction of domestic shale resources not only guarantees national security by ending reliance on energy imports but also flourishes national economy by creating new jobs (Kay, 2011). In addition, it is also claimed that shale gas with lower carbon emissions than coal means less pollution (Engelder, 2011). Nevertheless, the opponents argue that fracturing causes irreversible damage to ecosystems with the excessive (c) 2017 Zeynep Cihan Koca-Helvacı

This is an open-access article distributed under the terms of a Creative Commons Attribution License (http: $==$ creativecommons:org $=$ licenses $=b y=3: 0=$ ). 
use of water and toxic substances in the drilling process (Balaba \& Smart, 2012). Apart from this energy and water nexus, fracturing is also criticized for aggravating global warming by bringing methane gas to the surface (Burleson, 2012) and changing rural landscapes as a result of mushrooming of fracturing wells, an army of trucks, and gas workers (Smith \& Ferguson, 2013).

With rich shale resources, United States has witnessed an economic revival in the last decade as shale gas accounted for more than $40 \%$ of the total natural gas production in 2014 (US Energy Information Administration, 2015). However, the release of the movies Gasland (2010) and Promised Land (2012) have alarmed the society about the detrimental effects of fracturing on human life and environment. Noticing the intricate link between fracturing and contaminated water resources, American stakeholders have raised objections against shale gas extraction in their region (Finewood \& Stroup, 2012; Maykuth, 2011). The discursive aspects of this controversy lay the foundation for this study. The main objective of this research is to analyse the discursive strategies used by both sides of the public debate for legitimizing their own perspectives while delegitimizing the standpoint of their opponents.

On the pro-hydraulic fracturing side of the debate, there is the Marcellus Shale Coalition (hereafter MSC) which represents the energy, chemical and transportation companies that are engaged with shale business in the region. As the shale industry's top trade group within Pennsylvania, the coalition functions as the primary public face of the industry (Bomberg, 2013). For the anti-fracturing camp, the non-governmental organization Americans Against Fracking (hereafter $A A F$ ) was chosen because it is the largest coalition with members from environmental organizations, health institutions, labour unions and social justice groups. Press releases, reports, letters and newsletters published between July 2013 and July 2015 on each website were gathered to build a corpus. As my research aims at identifying the particular discursive strategies which enable the representation of a group and associated action either favourably or unfavourably, I focused on the referential or nomination strategies, predicational strategies and finally argumentation strategies within the framework of the Discourse-Historical Approach (hereafter DHA) (Wodak, 2001). While the first strategy is concerned with how social actors and actions of in- and out-groups are named, the second strategy deals with their evaluative attributions. Finally, argumentation strategies are concerned with topoi which are stock topics or argumentative formulations that provide standard patterns of logical associations between a claim and conclusion (Burgess et al., 2001). As rhetorical configurations, topoi enable legitimation of in-group action or delegitimation of out-group action. As my dataset was too big for an in-depth manual analysis, I also took advantage of corpus linguistics to obtain keywords, collocations, concordance lines and key semantic categories to examine these discursive strategies. My research questions are: 1. Which linguistic resources did the MSC and the AAF use to represent social actors of the in-group and out-group? 2. How was shale gas extraction represented linguistically in both corpora? 3. By means of what argumentation strategies did each organization justify its own standing while attacking the opponent's?

This article is divided into six sections. Following this introductory section, the Literature Review presents relevant research concerning the discursive structures in the representation of the shale gas controversy. The Methodology section explains the analytical framework by drawing upon the DHA and corpus linguistics. In the Data section, I provide information about data selection and collection methods. The Analysis presents how referential or nomination, predicational and argumentation strategies were used in each corpus. Finally, I discuss findings of the research in the Conclusion.

\section{Literature Review}

With its controversial nature, the extraction of unconventional energy resources has become a site of attention for Critical Discourse Analysis which aims at providing a critical perspective on structures of manipulative discourse concerning contentious issues (van Dijk, 1993). The 
never-ending strife between environmental protection and economic growth makes the discourse about the energy industry a rich database for linguistic analysis. Focusing on the coal seam gas extraction debate in Australia, Mercer, Rijke and Dressler (2014) examined the language use concerning the representation of effective regional development and role of economics in decision-making in advocate and opponent groups' media reports, promotional materials and website discussions over a one year period. It was seen that whilst the anti-coal seam gas group's discourse was shaped by health concerns and emphasis on irreplaceability, damage and interference, the discourse of the pro- coal seam gas group's discourse was based on growth and prosperity which are the basic constituents of the neoliberal mindset.

Being aware of the power of media in shaping public perception of energy problems, Jaspal and Nerlich (2014) adopted Thematic Analysis and Social Representations Theory to analyse pervasive rhetorical strategies in four British broadsheets' coverage of the fracking controversy at three critical points. The Guardian and the Independent with their left-ofcentre political standing tended to frame fracking as a threat to the environment and climate targets with reference to the movie Gasland (2010), the increasing seismic activity and carbon emissions. Conversely, the Times and the Daily Telegraph with their centre right perspective represented fracking as a solution for unemployment, economic slow-down and national security.

In another major study on British media's representation of the issue, Cotton et al. (2014) drew upon an argumentative discourse analytic approach to analyse dominant storylines in the British shale debate through stakeholder interviews and key policy actor statements in broadsheets. Whilst 'cleanliness and dirt', 'energy transitions' and 'geographies of environmental justice' were found to be the most dominant storylines, the government's intentional move to emphasize economic benefits while minimising the risk factors was noted. Bomberg (2015) also investigated the dominant discursive frames of the pro and antishale groups' discourse in the UK fracking debate between 2011 and 2014 to find out which frames became more visible throughout time. It was seen that in the pro-shale corpus, the economic promise and security frames remained visible across time whereas the reassurance frame, which was aimed at ensuring the public that shale was harmless, gradually became more dominant. On the contrary, the 'threat' and the 'fossil fuel lock-in' frames remained consistently strong in the anti-shale corpus whilst the bad-governance frame which underlined lack of transparency, democracy and citizen input in the policy making processes increased dramatically throughout the timeline. Another detailed study from the European fracking debate is on Poland which is one of the countries with prolific shale plays in the continent. Wagner (2015) investigated the role of experts and knowledge in Polish media with respect to the models of public communication on shale gas. The analysis was two-staged in which primarily frequency lists were generated to enable the qualitative analysis of the situational maps and discourse worlds. The outcome of the research has shown that shale gas was associated with the discursive field of uncertainty.

Another study on European shale debate is by Schirrmeister (2014) who studied storylines and future imagery in media and stakeholder discourses over hydraulic fracturing debate in Germany. The findings overlapped with the studies mentioned in this section as it was seen that there were six main storylines which are opportunity, economic growth, risky technology, conflict, climate change, possible geopolitic effects. Finally, considering the shale debate in the USA, a longitudinal study by Evensen, Clarke and Stedman (2014) examined how local newspapers of the Marcellus shale region reported on hydraulic fracturing. It was seen that the regional newspaper coverage of the issue is heavily dependent on the local discourse, especially information, ideas and opinions shared at public meetings. That is to say, when an area experienced more benefits, there was a positive coverage. The studies mentioned in this section showed that previous linguistic research on shale gas discourse tends to focus on macro-linguistic structures such as frames and storylines whereas micro- 
linguistic structures such as lexical choices, agency and argumentative strategies haven't been studied in much detail.

\section{Methodology}

In this section, the theoretical and analytical frameworks of the research were explained.

\subsection{Theoretical Framework}

Now that my focus is on discursive representations of pro and anti-fracturing camps over shale controversy in the USA, I made use of the DHA to analyse discursive strategies both blocs used to frame actors, action and argumentation to present a positive in-group and negative out-group image. Legitimation, which is central to both organizations' representation efforts, can be defined as a strategy that justifies a social activity through "good reasons, grounds, or acceptable motivations for past or present action" (Van Dijk, 1998, p. 255). The most pervasive and remarkable pattern in this persuasive process is unsurprisingly the development of an us versus them dichotomy that involves semantic strategies of positive ingroup and negative out-group presentation to gain approval (van Dijk, 1993). Considering the polarization of the society over the controversy of shale gas, each side shapes their discourse in a way to persuade the audience that their own standpoint is favorable and legitimate whereas the opponent's is undesirable and unjustifiable (Wodak, 2006). While the DHA puts stress on historical and current context of discourse, it also centres its attention on linguistic aspects by employing theories of argumentation, grammar and rhetoric to discover communicative patterns (Meyer, 2001). Therefore, a DHA analysis indicates a comprehensive investigation of the text both at the macro level by means of the historical, social and political background and at the micro level in terms of agency, causality and evaluative lexis.

Within the framework of the DHA, the identification of the discursive strategies which are intentional moves to attain particular social, political, psychological or linguistic goals (Reisigl \& Wodak, 2009), is central to explore discursive representation. Although the DHA provides five types of discursive strategies, I focused on three of them as it was my aim to explore how legitimation of the in-group and delegitimation of the out-group were realized in construction and representation of identities (Reisigl \& Wodak, 2009). First, the referential or nomination strategies deal with the linguistic construction of social actors in terms of their personal, kinship or occupational relations to each other. Second, predicational strategies are concerned with linguistic realizations of evaluative attributions related to social actors of ingroups and out-groups. By means of predication, social actors and actions are identified with reference to quality, quantity, space and time. This type of strategy cannot be sharply separated from the referential or nomination strategies. Third, argumentation strategies engage with a number of topoi which are widely used in persuasive rhetoric as topics or commonplaces to justify positive Self and negative Other representations (Balkin, 1996; Wodak, 2009). Reisigl and Wodak (2001) define topoi as content-related warrants or conclusion rules that establish a legitimate link between the argument and the conclusion or claim. As recurrent argumentation schemes which can be applied to different contexts (Anscombre, 1995), topoi guide the audience to draw a particular conclusion in a specific situation by means of providing a logical frame which is tightly linked to common sense, reasoning or doxa (Kienpointner, 1996). For example, the topos of advantage or usefulness can be used by two conflicting sides like the environmentalists and nuclear energy supporters to legitimize their viewpoints. The study of topoi has so far been limited to political and racist discourse (Reisigl \&Wodak, 2001; Richardson, 2004). As this paper was concerned with us vs. them dichotomy that is inscribed to our common sense reasoning, I took advantage of the relevant topoi from the list created by Wodak (2001, p.74) (See Table 1) to examine discriminatory discourse. 


\begin{tabular}{ll}
\hline 1. Usefulness, advantage & 9. Finances \\
2. Uselessness, disadvantage & 10. Reality \\
3. Definition, name-interpretation & 11. Numbers \\
4. Danger and threat & 12. Law and right \\
5. Humanitarianism & 13. History \\
6. Justice & 14. Culture \\
7. Responsibility & 15. Abuse \\
8. Burdening, weighting & \\
\hline
\end{tabular}

Table 1: List of topoi

\subsection{Analytical Framework}

While working within the framework of the DHA to analyse social actor and action representation as well as argumentation strategies, I also took advantage of corpus linguistics. Previous research (Baker \& McEnery, 2005; Gabrielatos \& Baker, 2008) has shown that triangulating corpus linguistics with a discourse analysis approach enables researchers to analyse large amounts of textual data objectively so the credibility of the analysis increases. For the purpose of this study, I used Wordsmith 6.0 (Scott, 2012) to obtain keywords as well as collocations and concordance lines of the search terms. Keyword lists, which are created automatically after statistical comparison of the frequent words in one corpus with a reference corpus, give us "a measure of saliency" (Baker, 2006). In line with Alexander (2009) who underlines the significance of keywords in diverting attention and backgrounding real problems, the keyword lists helped me investigate not only the lexical discrepancies between both corpora but also provide an insight into how both sides opted for framing the issue of fracturing.

With the help of the keyword lists, I obtained a set of search terms concerning shale gas extraction and prevalent social actors in $u s$ and them groups. In order to understand how shale gas extraction and relevant social actors were represented in both corpora within the scope of referential or nomination strategies and predicational strategies, I examined the frequent collocations and concordance lines of my search terms. Collocational analysis, which is concerned with the statistical co-occurrence of certain words, provides information about the most persistent and prominent ideas associated with a word (Gabrieletos \& Baker, 2008). Subsequently, I carried out concordance analysis which can be defined as "... simply a list of all of the occurrences of a particular search term in a corpus, presented within the context that they occur in; usually a few words to the left and right of the search term"'(Baker, 2006, p.71). The automatic display of my search terms within their contexts enabled me to see how the same search terms appeared in both discourses.

I also used Wmatrix software (Rayson, 2009) to automatically find out which semantic fields pervade the corpora of the MSC and the AAF. As Baker (2006) notes, whilst keyword lists display statistically significant differences between corpora, low frequency synonyms which are used to avoid repetition are ignored in the analysis. Analysis of the key semantic categories is a solution to this problem as general meaning is of greater importance than the meaning conveyed by single words. I used USAS semantic annotation set within Wmatrix which is based upon Longman Lexicon of Contemporary English (McArthur, 1981). This set is made up of a hierarchical system of semantic categories under 21 main discourse fields with 232 subcategories (see Archer, Wilson \& Rayson, 2002). The software groups words into semantic categories that are built upon some level of generality around the same mental concept. For instance, the category W is concerned with The World \& Our Environment whilst W1 is about The Universe and W2 is about Light. The semantic tagging of the corpus displays general categories of meaning used for the construction of discourse positions by 
opposing camps of debate (Baker, 2006). For the analysis of argumentation strategies namely topoi, I focused on the key semantic tags provided by the Wmatrix as these represent remarkably prevailing topics and associated argumentation schemes in the corpora of the $M S C$ and the AAF (Prentice, 2010).

\section{Data}

Two corpora were built from the documents of the MSC and the AAF. The MSC defines itself as an organization that works with exploration, production, midstream and supply chain partners in the U.S shale basins to address issues regarding "the production of clean, jobcreating American natural gas" (http://marcelluscoalition.org/). The second corpus was formed by the texts on the website of the $A A F$ which describes itself as a group of entities that aim at banning shale gas extraction to protect vital resources like drinking water and air (https://www.americansagainstfracking.org/). The texts were collected from press releases, newsletters and reports on both websites. After a detailed investigation, it was necessary to specify a time span limit for collection of the texts to have a balanced corpus. Although the earliest texts in both websites dated back to 2011, there was no even distribution over the years. Between July 2013 and July 2015, there were nearly an equal volume of texts on both websites. Therefore, I decided to collect the texts between those dates. Table 2 shows the size of both corpora.

\begin{tabular}{rlc}
\hline No & Name of Corpus & Number of words \\
\hline $\mathbf{1}$ & Marcellus Shale Coalition & 91,627 \\
$\mathbf{2}$ & Americans Against Fracking & 73,116 \\
Total & & $\mathbf{1 6 4 , 7 4 3}$ \\
\hline
\end{tabular}

Table 2: The size of corpus

\section{Analysis}

In order to provide an insight into the discourse worlds of these two opposite groups, keyword lists of both corpora were generated with the help of Wordsmith 6.0 (Scott, 2012) which conducts a statistical comparison between the word lists to find out unusually frequent words in each of them. The log-likelihood test in this tool automatically calculates the difference between statistical significance of the frequency contrast. Due to space limitations, only a limited number of keywords from each corpus were presented and discussed in the following paragraphs. Table 3 presents the 20 strongest keywords in the MSC corpus in comparison to the $A A F$ corpus.

The most striking finding in the keyword table of the MSC is the high frequency of the personal pronoun 'we' and possessive adjective 'our' whilst these were considerably less in the $A A F$ corpus. As function words, pronouns not only indicate language style but also disclose emotional states, personality and other features of social relationships (Chung \& Pennebaker, 2007). Such a prevalent use can be a result of the MSC's attempt to present a collective response to a rather contentious issue as 'we' not only shows a strong 'institutional identity' (Sacks, 1992), but also proves the consent of the majority (van Leeuwen, 2008). Previous research (Kacewicz, Pennebaker, Davis, Jeon \& Graesser, 2013) has also shown less use of first person singular pronouns and more use of first person plural pronouns by high status individuals, which implies being other-oriented. As an industry coalition working for the rights of the shale business companies in the region, the MSC puts emphasis on solidarity and altruism by using inclusive and positive sounding terms such as 'we' and 'our' while describing its aims and deeds. 


\begin{tabular}{llrrrrr}
\hline \multirow{2}{*}{ No } & Keyword & \multicolumn{2}{c}{ MSC } & AAF & \\
\cline { 2 - 5 } & & Freq. & \% & Freqness & \% & \\
\hline $\mathbf{1}$ & taxes & 454 & 0.54 & 20 & 0.02 & 447.43 \\
$\mathbf{2}$ & our & 505 & 0.60 & 93 & 0.12 & 270.68 \\
$\mathbf{3}$ & fees & 174 & 0.20 & 0 & 0.00 & 223.18 \\
$\mathbf{4}$ & businesses & 220 & 0.26 & 12 & 0.01 & 209.72 \\
$\mathbf{5}$ & opportunities & 195 & 0.23 & 9 & 0.00 & 190.92 \\
$\mathbf{6}$ & we & 462 & 0.55 & 116 & 0.15 & 186.97 \\
$\mathbf{7}$ & impact & 258 & 0.31 & 36 & 0.05 & 166.33 \\
$\mathbf{8}$ & manufacturing & 127 & 0.15 & 1 & 0.00 & 152.73 \\
$\mathbf{9}$ & Msc & 102 & 0.12 & 0 & 0.00 & 130.84 \\
$\mathbf{1 0}$ & revenues & 145 & 0.17 & 11 & 0.00 & 126.64 \\
$\mathbf{1 1}$ & commonwealth & 98 & 0.12 & 0 & 0.00 & 125.71 \\
$\mathbf{1 2}$ & growth & 157 & 0.19 & 17 & 0.02 & 115.48 \\
$\mathbf{1 3}$ & benefits & 208 & 0.25 & 42 & 0.05 & 106.40 \\
$\mathbf{1 4}$ & Pennslyvanians & 89 & 0.11 & 2 & 0.00 & 97.92 \\
$\mathbf{1 5}$ & severance & 75 & 0.09 & 0 & 0.00 & 96.19 \\
$\mathbf{1 6}$ & Wolf & 73 & 0.09 & 2 & 0.00 & 78.18 \\
$\mathbf{1 7}$ & work & 98 & 0.12 & 10 & 0.01 & 74.02 \\
$\mathbf{1 8}$ & development & 151 & 0.18 & 32 & 0.04 & 71.91 \\
$\mathbf{1 9}$ & support & 104 & 0.12 & 13 & 0.02 & 71.21 \\
$\mathbf{2 0}$ & union & 54 & 0.06 & 0 & 0.00 & 69.25 \\
& & & & & \\
\hline
\end{tabular}

Table 3: The 20 strongest keywords in the MSC corpus

The focus on 'people' can also be seen through the frequency of terms that show groups of people through 'commonwealth, union, Pennsylvanians and MSC'. This can be viewed as an attempt to create a sense of solidarity with the stakeholders by means of addressing a variety of social groups. The lexis is generally positive as the advantages of shale gas were underlined through vocabulary of finance (fees and revenues), jobs (work, business and manufacturing) and progress (growth, development). In addition, the shale business was represented as an act of philanthropy by means of 'benefits, opportunities, support, and impact'. On the other hand, the keywords of 'Wolf, severance and tax' show different discourse prosody as their concordances show a rather negative tone because Pennsylvania Governor Wolf planned to propose a severance tax on the shale industry. However, the tone on the whole is positive which is in line with Scollon (2008) who underlines the corporate attitude to background negative facts and events whereas foregrounding everything that can uphold their positive status or value. As textual meaning is created through relations of absence as well as presence (Richardson, 2007), I should underline that there are no keywords related to environmental issues.

Table 4 presents the keyword list of the AAF in comparison to the MSC. The keywords in the $A A F$ list can be grouped under three main headings. The first group includes the vocabulary related to the extraction through 'fracking, chemicals, fluids, wastewater, gallons' and shale related terms 'fossil, methane, benzene'. The second group contains vocabulary of natural resources like 'underground, wells and water'. The final group is concerned with the harmful effects of shale by means of keywords like 'climate, health, toxic, problems, contamination, pollution, watch'. 


\begin{tabular}{|c|c|c|c|c|c|c|}
\hline \multirow[t]{2}{*}{ No } & \multirow[t]{2}{*}{ Keyword } & \multicolumn{2}{|c|}{ AAF } & \multicolumn{2}{|c|}{ MSC } & \multirow[t]{2}{*}{ Keyness } \\
\hline & & Freq. & $\%$ & Freq. & $\%$ & \\
\hline 1 & Fracking & 1120 & 1.49 & 47 & 0.06 & 1350.10 \\
\hline 2 & water & 526 & 0.70 & 54 & 0.07 & 481.65 \\
\hline 3 & wells & 685 & 0.90 & 275 & 0.33 & 274.85 \\
\hline 4 & methane & 170 & 0.23 & 9 & 0.01 & 194.70 \\
\hline 5 & fluids & 188 & 0.24 & 22 & 0.03 & 169.36 \\
\hline 6 & climate & 148 & 0.20 & 10 & 0.01 & 159.83 \\
\hline 7 & pollution & 125 & 0.17 & 5 & 0.00 & 151.14 \\
\hline 8 & health & 201 & 0.27 & 34 & 0.04 & 150.24 \\
\hline 9 & wastewater & 108 & 0.14 & 2 & 0.00 & 144.23 \\
\hline 10 & contamination & 109 & 0.14 & 4 & 0.00 & 133.70 \\
\hline 11 & chemicals & 120 & 0.16 & 10 & 0.01 & 121.94 \\
\hline 12 & toxic & 74 & 0.10 & 0 & 0.00 & 110.75 \\
\hline 13 & PPINYS & 71 & 0.09 & 0 & 0.00 & 106.26 \\
\hline 14 & fossil & 81 & 0.11 & 3 & 0.00 & 99.19 \\
\hline 15 & EPA & 138 & 0.18 & 25 & 0.03 & 98.92 \\
\hline 16 & gallons & 64 & 0.08 & 1 & 0.00 & 86.73 \\
\hline 17 & watch & 68 & 0.09 & 2 & 0.00 & 86.17 \\
\hline 18 & problems & 89 & 0.12 & 9 & 0.01 & 84.62 \\
\hline 19 & benzene & 56 & 0.07 & 0 & 0.00 & 83.81 \\
\hline 20 & underground & 82 & 0.11 & 7 & 0.00 & 82.67 \\
\hline
\end{tabular}

Table 4: The 20 strongest keywords in the AAF corpus

Contrary to the positivity in the MSC keyword list, the tone in the $A A F$ list is rather negative, alarming and pessimistic. Another remarkable difference is the formal and scientific style in comparison with the personal style of the MSC. Institutional authorities like PPINYS (the Public Policy Institute of New York State) and EPA (Environmental Protection Agency) were the sources of reference. While foregrounding the negative aspects of the shale gas extraction, the absence of keywords showing benefits of shale is in accordance with the $A A F^{\prime}$ 's critical stance.

\subsection{Representation of Social Actors}

In regards of social actors, Martin-Rojo (1995) observed that the dichotomy between us vs. them draws a line between the inclusive $u s$ and exclusive them and prompts an ideological perspective that frames the included as ethical, beneficial and mentally superior while the excluded as immoral, vile and irrational. The comprehensive keyword list of the MSC shows that the in-group social actors were heavily represented in terms of 'we, industry and MSC' while the out-group was represented by 'Wolf'. Table 5 shows the collocations of the social actors in the MSC corpus. As the MSC is an organization that stands for the interests of the corporations and shareholders within the sector, it is quite normal for the in-group actors to be represented in terms of collective identities. Such use has an important role in manufacturing consent as van Leeuwen (2008, p.37) put an emphasis on the rule of majority in persuasion as "what most people consider legitimate" is seen as common sense. However, the out-group was represented by Governor Wolf in terms of individualization. The contradiction between 
us through collectivization and them by means of individualization is a deliberate effort to prove the legitimacy of the majority over the deviant minority.

\begin{tabular}{|c|c|c|c|c|c|}
\hline & No & $\begin{array}{c}\text { Us } \\
\text { Collocation }\end{array}$ & & No & $\begin{array}{c}\text { Them } \\
\text { Collocation }\end{array}$ \\
\hline We & 462 & $\begin{array}{l}\text { our, have, are, were, need, know, } \\
\text { see,make, work, think, continue, will, } \\
\text { must, can, able, gas, natural, shale, all, } \\
\text { more, better, co-operative, supportive, } \\
\text { dynamic }\end{array}$ & Wolf & 73 & $\begin{array}{l}\text { taxes, energy, proposed, proposal, } \\
\text { plan, plans, severance, higher, } \\
\text { governor, administration, natural, } \\
\text { damaging, threatening }\end{array}$ \\
\hline Msc & 102 & $\begin{array}{l}\text { president, companies, members, } \\
\text { committee, will, working, gas, advocates, } \\
\text { trusted, responsible, careful, leading }\end{array}$ & & & \\
\hline Industry & 461 & $\begin{array}{l}\text { gas, shale, natural, oil, our, energy, will, } \\
\text { impact, Marcellus, well, growth, taxes, } \\
\text { growing, support, state, businesses, } \\
\text { higher, want, needs, grow, economic, } \\
\text { continues, jobs, veterans, working, job, } \\
\text { work, public, opportunities, employment, } \\
\text { represent, development, fees, } \\
\text { commitment, companies, generates, } \\
\text { creates, contributes, increases, sponsors, } \\
\text { funds, dynamic, emerging, fastest- } \\
\text { growing }\end{array}$ & & & \\
\hline
\end{tabular}

Table 5: Collocations of social actors in the MSC corpus

Social actors within the $u s$ category were represented positively by means of lexis showing collective force (companies, members, committee, advocates, public, veterans, businesses), progress (work, make, continue, increase, grow, create, generate, emerging, fastest growing, growth, leading, dynamic, better, higher, development), financial benefits (job, employment, fees) altruism (cooperative, support, supportive, contribute, sponsor, fund, opportunity) and reliability (trusted, responsible, careful, commitment). The use of modality (will, can, be able to) also requires explanation as it indicates the writer/speaker's attitude towards the content or object of his/ her message (Hodge \& Kress, 1996). A closer look at the concordance lines of these modals shows that 'will' was used to show determination while 'can and be able to' were indicating the competence and power of the in-group social actors. (1) shows how the MSC praised its own activity with emphasis on self-dedication, communicative attitude, scientific evidence, transparency and benevolence:

(1)We are committed to being responsible members of the communities in which we work; we encourage spirited public dialogue and fact-based education about responsible shale gas development; and we conduct our business in a manner that will provide sustainable and broad-based economic and energy-security benefits for all (the MSC, 30.07.2015).

The only social actor in the them category was represented in terms of functionalization as a governor, for he was a high status social actor. Contrary to the positivity in the us category, he was described rather negatively through lexis implying financial burden (tax, taxes, higher, severance) and danger (damaging, threatening). Lexis about a hypothetical future (plan(s), proposed, proposal) reinforced the idea that it was necessary to stop the 
harmful plans of the Governor. In (2), we can see how Wolf was criticized in terms of destruction by oppressive, stunt, jeopardize, threatening, and reverse positive gains. He was represented as an obstacle before the economic prosperity promised by the shale industry. The discourse surrounding him was shaped by fear-inducing rhetoric with reference to the 2008 recession.

(2) Wolf is demanding oppressive new taxes that will stunt economic growth, job creation and our region's manufacturing potential. At the same time, critical impact tax funding would be jeopardized, threatening important local infrastructure investments. Marcellus Shale has been one of the few bright spots in a historically slow economic recovery. Gov. Wolf's actions seem designed to reverse these positive gains. (the MSC, 5.1.2015)

Table 6 below presents the social actors in us and them categories of the AAF corpus. Surprisingly, the actors in the us part are statistically less frequent than the ones in the them part. This difference can be seen as an indication of the AAF's attempt to focus on the negative qualities of the pro-shale group.

\begin{tabular}{|c|c|c|c|c|c|}
\hline & No & $\begin{array}{l}\text { Us } \\
\text { Collocation } \\
\end{array}$ & & $\begin{array}{l}\text { Them } \\
\text { No }\end{array}$ & Collocation \\
\hline We & 116 & $\begin{array}{l}\text { have, are, must, can, should, } \\
\text { will, need, do, know, our, } \\
\text { want, urge, depend, move, } \\
\text { drink, protect, responsible, } \\
\text { safeguarding }\end{array}$ & Industry & 328 & $\begin{array}{l}\text { gas, oil, fracking, shale, fossil, fuel, } \\
\text { pollution, wastes, water, energy, } \\
\text { natural, data, spending, unrestricted, } \\
\text { public, government, funded, access, } \\
\text { clen, climate, policy, drilled, harm, } \\
\text { emissions, lobbying, rhetoric, claims, } \\
\text { jobs, workers }\end{array}$ \\
\hline AAF & 18 & $\begin{array}{l}\text { Americans, national, coalition, } \\
\text { organization, water, science }\end{array}$ & PPINYS & 71 & $\begin{array}{l}\text { jobs, protection, scenario, claimed, } \\
\text { correction, incorrect, misused, } \\
\text { exaggerated, estimate }\end{array}$ \\
\hline & & & EPA & 138 & $\begin{array}{l}\text { water, drinking, standard, study, } \\
\text { investigation, administration, } \\
\text { released, report, wells, found, } \\
\text { methane, fracking, emission, } \\
\text { greenhouse }\end{array}$ \\
\hline
\end{tabular}

Table 6: Collocations of the social actors in the AAF corpus

The collocations of the in-group can be grouped under main headings of modality (must, will, can, need, should), volition (want, urge, demand), conservation (protect, responsible, safeguarding) and community (Americans, national, coalition, organization). A closer examination of the concordance lines of the modal verbs and expressions shows that deontic modality, which is "concerned with influencing actions, states or events" (Palmer, 1990, p.6) through emphasis on obligation, prohibition and advice, dominates the discourse of the $A A F$. Given that, we can say that the $A A F$ discourse was shaped by a call for immediate action to stop fracturing. The infrequency of the social actors in the $u s$ category may stem from the structure of the organization as the $A A F$ stands for loosely connected subgroups. As in (3), the 
subgroups which form the $A A F$ were frequently mentioned throughout the corpus to put stress on the heterogeneity and multivocality of the organization. Although the scarcity of the ingroup actors as a single body can be seen as a drawback, for it communicates a weak organizational attitude, the emphasis on subgroups can be viewed as an indication of the credibility and validity of the $A A F$ 's, goals which unite groups with different backgrounds and interests. The focus on diversity and numbers in (3) realized argumentum ad populum which refers to the wide support for justifying a viewpoint.

(3) On the public comment deadline for the Environmental Protection Agency's (EPA) proposed power plant rules, Americans Against Fracking, a national coalition to ban fracking, delivered a letter from over 250 environmental, health, labor and consumer protection groups, along with over 200,000 comments criticizing the rules for incentivizing fracked natural gas. (the $A A F, 1.12 .2014)$

The actors in the them part were not only more frequent but also identified in a more varied way. The collocations show that they were associated with wrongdoing (pollution, wastes, unrestricted, access, harm, greenhouse, emissions, methane), dishonesty (lobbying, rhetoric, claims, correction, incorrect, misused, exaggerated, scenario), environment (fossil, shale, water, oil, wells), bureaucracy (government, administration, policy). Although 'jobs and workers' and scientific research (investigation, study, found, data, estimate, release, report) seemed to be positive associations of this group, their concordance lines show that they were contextualized in a way to criticize the pro-shale group actors for distorting the truth about scientific evidence and job statistics. Criticism over honesty can be observed in (4) which blamed out-group social actors for telling lies to manufacture consent.

(4) New industry-sponsored study on fracking which is more spin than science produces findings dramatically out of step with recent studies (the $A A F, 16.09 .2013$ )

\subsection{Representation of shale gas extraction}

The second stage of my analysis is concerned with the representation of the shale gas extraction. That is, what is preferred of all the variety of choices and what qualities are attributed to the action. The comprehensive keyword lists of both corpora show that the extraction process was named as 'hydraulic fracturing, fracking and shale development'. In Table 7, we can see the distribution and representation of these terms in the MSC corpus. The least used term is obviously hydraulic fracturing, the collocations show that it was treated merely as a technical term. Fracking, which has negative connotations, was also used by the MSC with an attempt to embrace it rather than avoiding it (Zimmer, 2014). Although it was not used very often, the collocations such as favor and revolutionizing show that the industry tried to reverse the pejorative meaning loaded by the anti- shale groups. Despite these attempts to change the image of fracking, it is still seen that the pro-shale group heavily used a more neutral term shale development to represent the extraction process. While the term itself hides the negative aspects of drilling and fracturing, the associations are very positive. The collocations can be categorized into three main groups: community (farmers, commonwealth), innovation (job-creating, game-changing, renaissance, transformational, new, generate, opportunities), safety (safe, responsible, tightly-regulated). 


\begin{tabular}{lll}
\hline Action & No & Collocation \\
\hline Hydraulic fracturing & $\mathbf{2 5}$ & horizontal, drilling, natural, gas \\
Fracking & 47 & said, favor, help, revolutionizing, potential \\
& & \\
& & $\begin{array}{l}\text { continues, generates, supports, presents, } \\
\text { farmers, commonwealth, playing, tax, good, } \\
\text { new, opportunities, pervasive, game-changing, } \\
\text { job- creating, safe, responsible, renaissance, } \\
\text { tightly- regulated, transformational }\end{array}$ \\
& $\mathbf{1 3 9}$ & \\
\hline
\end{tabular}

Table 7: Representation of the extraction process in the MSC corpus

In (5), we can see how shale development was appreciated through security measures and its contribution to the job market.

(5) A new study released this week - Study of Construction Employment in Marcellus Shale Related Oil and Gas industry- highlights the clear jobcreating benefits tied to safe shale development across our labor force. (the $M S C, 17.10 .2014)$

Although the same terms were used in the $A A F$ corpus as well, there are substantial differences between the frequency and usage. Table 8 presents the distribution and lexical associations of the search terms in the $A A F$ corpus.

\begin{tabular}{lll}
\hline Action & No & Collocation \\
\hline Hydraulic fracturing 47 & injects, water, mixture, used, fluids, drinking \\
& \\
& $\begin{array}{l}\text { fluids, gas, water, groundwater,drinking, } \\
\text { wastewater, wells, oil, operation, chemicals, } \\
\text { chemical,natural, public, safe, environmental, } \\
\text { contamination, contaminate, pollution, period, } \\
\text { associated, sites,climate, cancer, risks, } \\
\end{array}$ \\
& $\mathbf{1 1 2 0}$ & $\begin{array}{l}\text { underground, dangerous, unsafe, methane, } \\
\text { increased, poses, polemical }\end{array}$ \\
& 32 & dangerous, risks, problems, controversial, costs \\
\hline
\end{tabular}

Table 8: Representation of the extraction process in the AAF corpus

As in the MSC corpus, hydraulic fracturing was used as a technical term. However, the collocations here involve the vocabulary related to the chemical solvent and its effects whilst 
in the MSC the term is concerned with the technique and product. Contrary to the MSC, shale development has the smallest share and it was associated with harm (dangerous, risks, problems, costs) and dissent (controversial). On the other hand, the pejorative term fracking was the most frequently used one in the $A A F$ corpus. The action was associated with environmental harm (wastewater, waste, chemicals, contamination, contaminate, pollution, methane), threat (cancer, risks, dangerous, unsafe, poses, polemical) and resources (fluids, gas, water, oil, groundwater, underground). As all these three terms were related to the actions of the industry which the $A A F$ opposed, the discourse concerning them was highly negative. In (8), fracking was identified as a menace to the environmental heritage of Americans through emotive vocabulary such as national treasure, sacred trust which aims at evoking nationalistic feelings.

(8) "Our public lands are a national treasure and a sacred trust passed by one generation of Americans to another," said Drew Hudson of Environmental Action. "Fracking on public lands threatens the drinking water of millions of people, including the President's daughters and everyone else here in Washington, D.C. It would also poison many of our last wild and pristine ecosystems. (the $A A F, 22.08 .2013$ )

\subsection{Argumentative schemes}

In this section, the interplay between key semantic categories and argumentative schemes namely topoi were studied to analyze the construction of discourse positions on the different sides of the shale controversy. The USAS annotation system within Wmatrix generated comparative lists of key semantic categories for both corpora. As I was mainly interested in topoi, I only focus on the semantic categories which instantiated argumentative schemes in both tables. In Table 9, the key semantic categories in the MSC corpus in comparison to the $A A F$ corpus can be viewed. The most prevalent argumentative scheme is the topos of advantage or usefulness which means "if an action under a specific relevant point of view will be useful, then one should perform it" (Wodak, 2001, p.74). Through the categories of Helping (support, benefit, promote, encourage, boost), Chance, luck (opportunity, chance), Size: big (growth, expansion, substantial), Evaluation: good (advance, progress, recover, advantage), the industrial activity advocated by the $M S C$ was praised for contributing positively to American social welfare. The subcategory of this topos is pro bono publico (to the advantage of all) for the shale industry was framed as a savior for the whole American nation who suffered from the recession.

The categories concerning money $(2,16,18)$, work $(7)$, business $(3,14)$ were also concerned with the topos of advantage or usefulness by means of specifying the benefits of shale for the job market and regional economy. However, the concordance lines of the money-related categories were also framed by the topos of danger and threat which indicates that "if a political action or decision bears specific dangerous, threatening consequences, one should not perform or do it" (Wodak, 2001, p.75) with a focus on the harms of prospective tax rise for the shale industry. This topos led to a victim-victimizer reversal in which the proshale group casts itself into the role of the victim who was threatened by oppressive tax schemes in return of their contribution to American welfare. The issue of tax rise was also characterized by the topos of finance which means "if a specific situation or action costs too much money or causes a loss of revenue, one should perform actions which diminish the costs or help to avoid the loss" (Wodak, 2001, p.76). 


\begin{tabular}{|c|c|c|c|c|c|c|}
\hline \multirow[t]{2}{*}{$\overline{\text { No }}$} & \multirow[t]{2}{*}{ Semantic Category } & \multicolumn{2}{|c|}{ MSC } & \multicolumn{2}{|c|}{ AAF } & \multirow[t]{2}{*}{ Keyness } \\
\hline & & Freq. & $\%$ & Freq. & $\%$ & \\
\hline 1 & Pronouns & 3952 & 5.14 & 1962 & 2.83 & 491.05 \\
\hline 2 & Money and pay & 981 & 1.28 & 203 & 0.29 & 478.33 \\
\hline 3 & Business:Generally & 835 & 1.09 & 246 & 0.36 & 280.46 \\
\hline 4 & Helping & 873 & 1.14 & 300 & 0.43 & 235.58 \\
\hline 5 & Speech: Communicative & 723 & 0.94 & 239 & 0.35 & 207.04 \\
\hline 6 & Personal names & 827 & 1.08 & 335 & 0.48 & 166.79 \\
\hline 7 & Work and employment: Generally & 826 & 1.07 & 367 & 0.53 & 136.53 \\
\hline 8 & Time: Future & 546 & 0.71 & 211 & 0.30 & 120.57 \\
\hline 9 & Chance, luck & 211 & 0.27 & 39 & 0.06 & 112.79 \\
\hline 10 & Participating & 121 & 0.16 & 11 & 0.02 & 96.13 \\
\hline 11 & Warfare, defence and the army; weapons & 141 & 0.18 & 21 & 0.03 & 87.52 \\
\hline 12 & Size: big & 433 & 0.56 & 185 & 0.27 & 78.15 \\
\hline 13 & Government & 773 & 1.01 & 416 & 0.60 & 74.80 \\
\hline 14 & Business: Selling & 459 & 0.60 & 206 & 0.30 & 74.10 \\
\hline 15 & Politics & 288 & 0.37 & 103 & 0.15 & 72.87 \\
\hline 16 & Money: Cost and Price & 405 & 0.53 & 174 & 0.25 & 72.22 \\
\hline 17 & Evaluation: Good & 417 & 0.54 & 200 & 0.29 & 56.98 \\
\hline 18 & Money generally & 222 & 0.29 & 79 & 0.11 & 56.63 \\
\hline 19 & Places & 1000 & 1.30 & 618 & 0.89 & 55.54 \\
\hline 20 & Belonging to a group & 813 & 1.06 & 502 & 0.73 & 45.34 \\
\hline
\end{tabular}

Table 9: The 20 Strongest semantic categories in the MSC Corpus

The categories of Politics and Government show that the MSC tried to convince the politicians to oppose the tax regulation. As exemplified in (9), with reference to negative socio-economic consequences of a prospective tax rise, the MSC addressed a variety of stakeholders to stand against this legislation. The word 'sting' was used as a metaphor to identify anti-shale politicians in Harrisburg as insects that would cause harm to Pennsylvanians. Those in opposition were also criticized for being irrational with reference to the need for common sense policies.

(9) As some in Harrisburg seek to pass even higher energy taxes that would sting Pennsylvania consumers and families, local officials across the political spectrum, building and labor trade unions as well as small businesses are speaking out loudly, clearly and in a united voice for common sense policies that create jobs and opportunities. (the MSC, 5.05.2015)

Table 10 below presents the top 20 key semantic categories in the $A A F$ corpus with comparison to the MSC. As in the MSC, only the semantic categories that were identified with topoi were discussed. The most pervasive argumentation scheme is the topos of danger and threat which was instantiated through the categories of Disease (cancer, symptoms, headache), Green issues (pollution, contaminants, EPA, environmental resources), Damaging and destroying (destructive, harmful, accident, leaks, ruin), Medicines and medical treatment (public health, hospital), Weather (climate change, drought), Danger (risky, dangerous, hazards), Temperature: Hot/ on fire (burning, global warming) and Violent/ Angry (aggressive, attack, threaten). This topos is closely linked with the topos of burdening or weighing down which can be described as "if a person, an institution or a country is burdened by specific problems, one should act in order to diminish these burdens" (Wodak, 2001, p.76). 


\begin{tabular}{|c|c|c|c|c|c|c|}
\hline \multirow[t]{2}{*}{ No } & \multirow[t]{2}{*}{ Semantic Category } & \multicolumn{2}{|c|}{ AAF } & \multicolumn{2}{|c|}{ MSC } & \multirow[t]{2}{*}{ Keyness } \\
\hline & & Freq. & $\%$ & Freq. & $\%$ & \\
\hline 1 & Substances and materials: Liquid & 1339 & 1.93 & 324 & 0.42 & 775.80 \\
\hline 2 & Geographical terms & 936 & 1.35 & 352 & 0.46 & 339.25 \\
\hline 3 & Disease & 451 & 0.65 & 79 & 0.10 & 328.72 \\
\hline 4 & Substances and materials: Gas & 1474 & 2.13 & 861 & 1.12 & 233.26 \\
\hline 5 & Substances and materials Generally & 431 & 0.62 & 121 & 0.16 & 218.16 \\
\hline 6 & Green issues & 541 & 0.78 & 208 & 0.27 & 190.20 \\
\hline 7 & Damaging and destroying & 270 & 0.39 & 54 & 0.07 & 180.65 \\
\hline 8 & Weather & 198 & 0.29 & 28 & 0.04 & 162.36 \\
\hline 9 & Danger & 270 & 0.39 & 74 & 0.10 & 140.09 \\
\hline 10 & Drinks and alcohol & 165 & 0.24 & 28 & 0.04 & 122.56 \\
\hline 11 & Substances and materials: Solid & 268 & 0.39 & 84 & 0.11 & 121.31 \\
\hline 12 & No constraint & 248 & 0.36 & 74 & 0.10 & 118.30 \\
\hline 13 & Medicines and medical treatment & 308 & 0.44 & 119 & 0.15 & 107.54 \\
\hline 14 & Deciding & 152 & 0.22 & 34 & 0.04 & 93.76 \\
\hline 15 & Not allowed & 79 & 0.11 & 6 & 0.01 & 82.32 \\
\hline 16 & Exceed; waste & 181 & 0.26 & 61 & 0.08 & 75.42 \\
\hline 17 & Temperature: Hot/on fire & 119 & 0.17 & 31 & 0.04 & 64.70 \\
\hline 18 & Numbers & 1375 & 1.99 & 1119 & 1.46 & 59.88 \\
\hline 19 & Violent/Angry & 189 & 0.27 & 85 & 0.11 & 52.10 \\
\hline 20 & Difficult & 149 & 0.22 & 60 & 0.08 & 49.01 \\
\hline
\end{tabular}

Table 10: The 20 Strongest semantic categories in the AAF Corpus

The categories of Exceed; waste (waste, over) and Difficult (problems, crisis, challenge, difficulty) are also related with the topos of burdening or weighing down. The opposition of the anti-shale group was legitimized through representation of the shale industry not only as a threat but also as a burden for natural resources and public health. The concordance lines showed that governmental action was demanded to reduce the harms of fracturing.

The topos of abuse, which can be paraphrased as if a right is misused, measures must be taken to stop the abuse (Wodak, 2001), was also employed to criticize legal loopholes which enabled the corporate abuse of the environment through the category of No constraint (unrestricted, unchecked, lax). The present and future effects of this unrestrained industrial activity were also represented in terms of the topos of numbers which states that "if the numbers prove a specific topos, a specific action should be performed or not be carried out" (Wodak, 2001, p.76). Here, the statistical data not only aggravated the negative projections of the AAF but also presented the propositions as more verifiable (Semin \& Fiedler, 1988), true (Hansen \& Wanke, 2010) and probable (Tversky \&Kahneman, 1982).

The last argumentation scheme is the topos of responsibility which can be summarized as if a state or group creates a problem, they should resolve it (Wodak, 2001). This topos was instantiated by the category Not Allowed (ban, prohibit, suppression) which underlined the anti-shale group's demand for government action to regulate industrial activity rather than encouraging it for the sake of political and economic gains. In (10), we can observe topos of danger and threat as well as topos of responsibility. The negative tone was sharpened by alarming vocabulary (poison, toxic, threaten) and focus on children. The reference to the 'investigation by the Pulitzer Prize winning journalists' is argumentum ad verecundiam as the author portrayed the journalists as a credible authority without providing any scientific data 
about their research. The validity of the $A A F$ 's perspective was also aimed to be strengthened by means of 'hundreds of complaints' which is an example of argumentum ad populum as it represented the opposition as a widely held view.

(10) The 8-month 'Fracking the Eagle Ford Shale' investigation by Pulitzer Prize winning journalists reveals that fracking is literally poisoning the air children and families breathe. Polluted with toxic chemicals like hydrogen sulfide and benzene, air poisoned by fracking is entering homes, daycare centers and schools throughout entire regions. This investigation and the hundreds of complaints build on an already significant body of science showing that fracking inherently poisons the air and threatens people's health. For the sake of our health and the wellbeing of our communities, fracking must be banned. (the $A A F, 18.02$. 2014)

\section{Conclusion}

This study set out with the aim of finding discursive strategies adopted by two opposite groups to justify their standpoint in the fracturing controversy. Considering the discourse of the pro-shale group, the findings of the study are consistent with the results of previous research (Mercer, Rijke \& Dressler, 2014; Jaspal \& Nerlich, 2014), as the discourse of the MSC which champions the shale gas industry was largely shaped by the identification of shale gas with financial gains, job opportunities, social welfare, nationalism, and philanthropy. This organization's fixation with industrial growth, economic profits, reduced governmental intervention and tax reductions overlap with neoliberalism which regards environment as a mere instrument for the generation of economic gains for human beings (Egri \& Pinfield, 1996). In order to fend off criticism concerning commodification of nature for corporate interests, the MSC frequently underlined that the whole American nation were the beneficiaries of their industrial manufacturing. The focus on regional pride associated with energy production and collective benefits portrays extraction as "classless and horizontally beneficial to all members of the community" (Gaventa, 1982, p.58) with an intention to mask the corporations' profits and environmental harm. For residential support, master narratives of nationalism and 'American Dream' with reference to progress, prosperity and power (Bell \& York, 2010) were used. Therefore, bans and tax regulations were framed as attacks on national interests. The MSC also took advantage of intimidating rhetoric by establishing a cause and effect link between tax rise and economic recession. The most striking finding about this corpus is the highly positive representation of the in-group actors and actions with an emphasis on collective aims and gains. The topos of advantage or usefulness also contributed to this positive 'Self representation'. On the other hand, negative 'Other representation' was considerably less and only built upon criticism towards government regulation.

The results concerning the discourse of the anti-shale group $A A F$ corroborate the findings of Jaspal and Nerlich (2014), Mercer, Rijke and Dressler (2014) and Bomberg (2015) as shale gas was associated with threat. As a pro-environmental group, the discourse of the AAF is educating, alerting and mobilizing (Cox, 2010) through negative associations of shale gas with irreversible environmental damage and threat to human health. The term 'fracking' was defined through lexis showing disease, destruction and demise. In line with Anderson (1997) who underlined the importance of using themes that people can easily identify with, the AAF largely built its discourse on the drinking water problem and health hazards. This group also took advantage of nationalism by putting stress on the vitality of protecting the ecosystem of the US. Scientific evidence and statistical data as authoritative resources (Ozawa, 1996) were used to persuade the stakeholders to unite against the shale gas extraction. It is interesting to 
note that this group built its discourse upon negative 'Other representation' whilst there was remarkably less emphasis on its own group identity.

To prove their organizational legitimacy, both sides of the controversy shaped their discourses in a way to create the image of a proper and beneficial entity that conformed to the norms, interests, definitions and values of the American society (Suchman, 1995). By means of triangulating quantitative and qualitative analysis to explore the discourses surrounding water-energy nexus which is an increasingly important area in the US, this study not only adds to the literature on Self and Other representation but also contributes to the linguistic analysis of environmental controversies.

\section{References}

Richard Alexander (2009). Framing discourse on the environment: A critical discourse approach. Routledge, New York/ London.

Alison Anderson (1997). Media, Culture and the Environment. UCL Press, London.

Jean-Claude Anscombre (editor) (1995). Théorie des topoi. Editions Kimé, Paris.

Dawn Archer, Andrew Wilson and Paul Rayson (2002). Introduction to the USAS category system: Benedict project report. Available online at http://ucrel.lancs.ac.uk/usas/ usas\% 20guide.pdf.

Paul Baker and Tony McEnery (2005). A corpus-based approach to discourses of refugees and asylum seekers in UN and newspaper texts. Language and Politics, 4 (2), 197-226.

Paul Baker (2006). Using Corpora in Discourse Analysis. Continuum, London/ New York.

Ronald S. Balaba and Ronald B. Smart (2012). Total arsenic and selenium analysis in Marcellus shale, high-salinity water, and hydrofracture flowback wastewater. Chemosphere, 89 (11), 1437-1442.

Shannon Elizabeth Bell and Richard York (2010). Community economic identity: The coal industry and ideology construction in West Virginia. Rural Sociology, 75(1), 111-143.

Elizabeth Bomberg (2013). The Comparative Politics of Fracking: Networks and Framing in the US and Europe. APSA 2013 Annual Meeting Paper; American Political Science Association 2013 Annual Meeting. Available online at https://ssrn.com/ abstract $=230$ $\underline{1196}$

Elizabeth Bomberg (2015). 'Shale We Drill? Discourse Dynamics in UK Fracking Debates' Journal of Environmental Policy and Planning, 1-17.

Jonathan Burgess, Emily Kneebone, Vaios Liapis and Laura Swift (2001, November 01). Topos. The Literary Encyclopedia. Volume 1.1.1: Archaic, Classical, Hellenistic and Imperial Greek Writing and Culture, -800--100. Available online at https:// www. litencyc.com/php/stopics.php?rec=true \&UID $=1126$

Elizabeth Burleson (2012). Cooperative federalism and hydraulic fracturing: A human right to a clean environment. Cornell Journal of Law and Public Policy, 22, 289- 348. 
Cindy Chung and James Pennebaker (2007). The psychological function of function words. In K. Fiedler (Ed.), Frontiers of social psychology , 343-359. New York, NY: Psychological Press.

Matthew Cotton, Imogen Rattle and James Van Alstine (2014). Shale gas policy in the UK. An argumentative discourse analysis. Energy Policy 73, 427-38.

Robert Cox (2010). Environmental Communication and the Public Sphere. Sage, California.

Carolyn P. Egri, C. and Lawrence T. Pinfield (1996). Organizations and the biosphere: Ecologies and environments. In Stewart R. Clegg, Cynthia Hardy and Walter R. Nord (editors), Handbook of organization studies , 459-483. Sage, London.

Terry Engelder (2011). Should fracking stop?. Nature, 477, 274-275.

Darrick Evensen, Chris Clarke and Richard C.Stedman (2014). A New York or Pennsylvania state of mind: social representations in newspaper coverage of gas development in the Marcellus Shale. Journal of Environmental Studies and Sciences , 4:65-77.

Michael H. Finewood and Laura Stroup (2012). Fracking and the neoliberalization of the hydrosocial cycle in Pennsylvania's Marcellus Shale. Journal of Contemporary Water Research \& Education, 147, 72-79.

Costas Gabrielatos and Paul Baker (2008). Fleeing, sneaking, flooding: A corpus analysis of discursive constructions of refugees and asylum seekers in the UK press, 1996-2005. Journal of English Linguistics, 36, 5-38.

John Gaventa (1982). Power and powerlessness: Quiescence and rebellion in an Appalachian valley. University of Chicago Press, Chicago, IL.

Jochim Hansen, J and Michaela Wanke (2010). Truth from language and truth from fit: The impact of linguistic concreteness and level of construal on subjective truth. Personality and Social Psychology Bulletin, 36, 1576-1588.

Robert Hodge and Günther Kress (1996). Language as ideology. Routledge, London.

Rusi Jaspal and Brigette Nerlich (2014). Fracking in the UK press: Threat dynamics in an unfolding debate. Public Understanding of Science, 23 (3), 348-363.

Ewa Kacewicz, James Pennebaker, Matthew Davis, Moongee Jeon and Arthur Graesser. (2013). Pronoun Use Reflects Standings in Social Hierarchies. Journal of Language and Social Psychology, XX(X) 1-19.

David Kay (2011). The economic impact of Marcellus shale gas drilling: What have we learned? what are the limitations?. Working Paper Series: A Comprehensive Economic Analysis of Natural Gas Extraction in the Marcellus Shale. Cornell University Press, New York.

Manfred Kienpointner (1996). Vernunftig argumentieren: Regeln und Techniken der Diskussion. Rowohlt, Hamburg.

Luisa Martin-Rojo (1995). Division and rejection: from the personification of the Gulf 
conflict to the demonization of Saddam Hussein. Discourse \& Society, 6(1), 49-80.

Andrew Maykuth (2011, April 18). Strong positions on either side of "fracking" at EPA hearing. Philadelphia Inquirer. Available online at http://www.philly.com/philly/news/special_packages/inquirer/marcellus-shale /2010 0914 Strong_positions_on_either_side_of quot_fracking_quot_at_EPA_hear ing.html

Tom McArthur (1981). Longman lexicon of contemporary English. Longman, London.

Alexandra Mercer, Kim de Rijke, Wolfram Dressler (2014). Silences in the boom: coal seam gas, neoliberalizing discourse, and the future of regional Australia. Journal of Political Ecology, 21, 279-302.

Michael Meyer (2001). Between theory, method and politics: Positioning of the approaches to CDA. In Ruth Wodak and Michael Meyer (editors), Methods of Critical Discourse Analysis (pp. 14-31). Sage, London.

Connie P. Ozawa (1996). Science in environmental conflicts. Sociological Perspectives, 39(2), 219-231.

Frank Robert Palmer (1990). Modality and the English Modals. Longman, London.

Sherly Prentice (2010). Using automated semantic tagging in Critical Discourse Analysis: A case study on Scottish independence from a Scottish nationalist perspective. Discourse \& Society, 21, 405-437.

Paul Rayson (2009). Wmatrix: a web-based corpus processing environment, Computing Department, Lancaster University. Available online at http:/ucrel.lancs.ac.uk/wmatrix/

Martin Reisigl and Ruth Wodak (2001). Discourse and discrimination: Rhetorics of racism and anti-Semitism. Routledge, London.

Martin Reisigl and Ruth Wodak (2009). The discourse-historical approach (DHA). In Ruth Wodak \& Michael. Meyer (editors) Methods of Critical Discourse Analysis, 2nd edn (pp. 87-121). Sage, London.

John E. Richardson (2004). (Mis)Representing Islam: The racism and rhetoric of British broadsheet newspapers. John Benjamins Publishing, Amsterdam/ Philadelphia.

John E. Richardson (2007). Analysing Newspapers: An approach from Critical Discourse Analysis. Palgrave Macmillan, Hampshire/ New York.

Harvey Sacks (1992). Lectures on Conversations (Vol. 1 and 2). Blackwell, Oxford.

Mira Schirrmeister (2014). Controversial futures-discourse analysis on utilizing the "fracking" technology in Germany. Eur J Futures Res, 2, 38-46.

Ron Scollon (2008). Analyzing Public Discourse: Discourse Analysis in the Making of Public Policy. Routledge, London.

Mike Scott (2012). WordSmith Tools version 6. Stroud: Lexical Analysis Software. 
Giin R. Semin and Klaus Fiedler (1988). The cognitive function of linguistic categories in describing persons: Social cognition and language. Journal of Personality and Social Psychology, 54, 558-568.

Michael F. Smith and Denise P. Ferguson (2013). Fracking democracy: Issue management and locus of policy decision-making in the Marcellus Shale gas drilling debate. Public Relations Review, 30, 377-386.

Mark C. Suchman (1995). Managing legitimacy: strategic and institutional approaches. Academy of Management Review, 20 (3), 571-610.

Amos Tversky and Daniel Kahneman (1982). Judgments of and by representativeness. In Daniel Kahneman, Paul Slovic and Amos Tversky (editors.), Judgment under uncertainty: Heuristics and biases (pp. 84-100). Cambridge University Press, Cambridge, UK.

US Energy Information Administration. (2015). Annual energy outlook. Washington, DC: U.S. Department of Energy.

Teun Van Dijk (1993). Elite Discourse and Racism. Sage, Newbury Park, CA.

Teun Van Dijk (1998). Ideology: A Multidisciplinary Approach. Sage, Newbury Park, CA.

Theo van Leeuwen (2008). Discourse and Practice. Oxford University Press, New York.

Aleksandra Wagner (2015). Shale gas: Energy innovation in a (non-)knowledge society: A press discourse analysis. Science and Public Policy, 42, 273-286.

Ruth Wodak (2001). The discourse-historical approach. In Ruth Wodak and Michael Meyer (editors), Methods of critical discourse analysis (pp. 63-94). Sage, London.

Ruth Wodak (2006). History in the making/ The making of history: The 'German Wehrmacht' in collective and individual memories in Austria. Journal of Language and Politics, 5(1), 25-54.

Ben Zimmer (2014, October 3). A Push to make 'Fracking' sound better. Can the word lose its bad reputation?. The Wall Street Journal. Available online at http://www.wsj.com/articles/can-the-word-fracking-lose-its-bad-reputation1412358270 